\title{
Teacher Education and Development in Nigeria: An Analysis of Reforms, Challenges and Prospects
}

\author{
Ogunyinka, Emmanuel Kayode ${ }^{1}$, Okeke, Tochukwu Innocent ${ }^{2}$, Adedoyin, Ronke Charity ${ }^{3}$ \\ ${ }^{1}$ College of Education, Central China Normal University, Wuhan, China \\ ${ }^{2}$ Department of History, University of Abuja, Abuja, Nigeria \\ ${ }^{3}$ Panacea Global Academy, Akure, Ondo State, Nigeria \\ Email address: \\ kaysmart_89@yahoo.com (E. K. Ogunyinka),okeketoo@yahoo.com (T. I. Okeke), mcpetersronke@yahoo.com (R. C. Adedoyin)
}

\section{To cite this article:}

Ogunyinka, Emmanuel Kayode, Okeke Tochukwu Innocent, Adedoyin, Ronke Charity. Teacher Education and Development in Nigeria: An Analysis of Reforms, Challenges and Prospects. Education Journal. Vol. 4, No. 3, 2015, pp. 111-122. doi: 10.11648/j.edu.20150403.14

\begin{abstract}
Although teacher education, both pre-and in-service, programs are offered in Nigeria by different teacher education institutions (as provided in the National Policy on Education), and varying degrees of success recorded, various problems still confront the program with far reaching consequences in Nigeria's educational system. This paper talks about the need for teacher education, the ideal teacher education, teacher education and national development, analyses the historical contexts of the teacher education reforms and development in Nigeria with emphasis on the roles of the Christian missions, the colonial administration and that of the Nigerian government after independence. It examines key recommendations of two commissions (Phelps Stokes and Ashby) and their implications to the reform and development of teacher education in Nigeria both during colonial era and after independence. The paper further discusses the influence of these and other reforms in shaping teacher education in Nigeria, the challenges still facing it, and finally suggests solutions and a holistic approach to better the lots of teacher education in Nigeria.
\end{abstract}

Keywords: Teacher Education, Development, Reforms, Challenges, Prospects

\section{Introduction}

Teacher education refers to professional education of teachers towards attainment of attitudes, skills and knowledge considered desirable so as to make them efficient and effective in their work, in accordance with the need of a given society at any point in time. It includes training and or education occurring before commencement of service (preservice) and during service (in-service or on-the-job). Every society requires adequate human and material resources to improve its social organization, preserve the culture, enhance economic development and reform the political structures. Education is often seen as a prerequisite for quality manpower development and creation of wealth, a sure path to success in life and service to humanity. Thus, teachers have important role to play to adequately prepare the young for their roles in the society in order to achieve the set national objectives.

Education is an inevitable tool for sustainable development and a vehicle for advancing the frontier of knowledge (Abdul-Kareem, 2001). In this regard, education is severally conceived and inculcated by people of varying backgrounds, ages, needs and aspirations for sustainable development. The potency of education is more evident in its globalization trends imbued with instrumental values of nurturing productive citizens for sustainable development and democracy. Education has been recognized as a process of imparting knowledge, skills and attitudes to the learners. Teachers' influence is always felt in every aspect of the society. The effectiveness of any educational system depends greatly on the educational attainment of teachers because no system of education can be qualitatively higher than the quality and commitment of its teachers.

The fact remains that teaching and learning depend on teachers for there can be no meaningful socio-economic and political development in any country without teachers. It is on teachers' numbers, quality and devotion that rest the effectiveness of all educational arrangements, development and growth. Even the educational planners may have the best educational policies and designs, the government may vote the largest sum of its revenue to education, but the ultimate realization of any set of aims for education depends on the teacher. It is the teacher who will ultimately be responsible 
for translating policy into action and principles into practice in their interactions with their students. (Ukeje, 1996) supported this fact when he stated that education unlocks the door to modernization, and added that it is the teachers who hold the key to that door. (Afe, 1992), states that the realization of the educational objectives depends on the quality and quantity of the available teaching manpower. This can be influence by the availability of adequate training and retraining programmes for those about to teach and those already teaching respectively. Hence, the efficiency of teacher training should be the main determining factor in the success or failure of education to meet the country's needs. The training is the policies and procedures designed to equip prospective teachers with the knowledge, attitudes and skills they require to perform their tasks effectively in the classroom, school and wider community. Education is the most powerful instrument for social and economic progress. It is the greatest power get known to man for his her own improvements. Teachers are the heart and soul of the educational enterprises, indeed, the life of the school system depends on them.

Teachers belong to the profession which has the only potential of determining the social, economic, political and moral destiny of every Nigerian citizen. This fact underscores the necessity for teacher education to be perceived as a sacred duty that must never be toyed with if teaching must fulfill its divine professional mandate of cultivating generations of highly responsible disciplined and useful Nigerians. However, teacher education should be regarded as the bedrock for national development. (Talabi, 1985) (Bofarin, 1986) (Afe, 1995) the major problem facing the nation has been that of getting teachers of quality. For teacher quality to rise above the educational system, a strong teacher education programme is required. This paper talks about the need for teacher education, the ideal teacher education, teacher education and national development, reviews the historical development of teacher education in Nigeria, and further examines teacher education reforms as undertaken by Phelp-Stokes and Ashby commissions, Nigeria regional governments, as well as the postindependence efforts. Subsequently, the paper identifies and discusses the challenges facing teacher education in the country and give suggestions towards improving the system.

\subsection{The Need for Teacher Education}

Teacher education is policies and procedures designed to equip prospective teachers with the knowledge, attitude, behaviors and skills they require to perform their tasks effectively in the classroom, school, the church/mosque and the local and wider society. Although, ideally it should be conceived of and organized as a seamless continuum, teacher education is often divided into three stages:

- Initial teacher training (teacher candidates)

- Induction (the process of providing training and support during the first few year of teaching or the first year in a particular school).

- Teacher development or continuing professional development (CPD) (an intensive process for practicing teachers).

\subsection{The Ideal Teacher Education}

According to (Adewuyi and Ogunwuyi, 2002), opined that teacher education is the provision of professional education and specialized training within a specified period for the preparation of individuals who intends to develop and nurture the young ones into responsible and productive citizens. It is informed by the fact that teaching is an all-purpose profession which stimulates the development of mental, physical and emotional powers of students. Such educated citizens would be sensitive and equipped with peaceful coexistence, environmental management and democratic process.

The heartbeat of manpower development and training for prudent use and sustenance of resources in nation building is teacher education. Teacher education, being inextricably linked with general education and social goals, is constantly caught up in the series of dilemmas derivable from educational expansion, political, technological development and social change. The prevailing crisis in Nigerian education and its society as typified by unemployment, poverty, corruption, crime, indiscipline and underutilization of capacities in all facets of human life and national development, could be ascribed to the neglect of teacher education and pitiable plight of the teachers. All these conflictual relationships precipitated poverty-induced hardships across all segments of the Nigerian community. What structurally becomes important in achieving the nation's quest for self-reliant society, imbued with vibrant economy and productive citizenry, is to put in place a comprehensive teacher education programme (Adewuyi, 2012). (Ogunwuyi, 2010) contends that education should be globally adopted as an agent of change and stability to promote probity, equity and equality of opportunities and a launching pad for sustainable human development. Herein, teacher education should embrace and radiate the energizing forces of change backed up purposefully by democratic leadership and rational economic policies. This provides the basis for sustainable development and environment which largely facilitate harmonious creation of wealth and wellbeing of humanity.

The importance of education as a weapon against ignorance, conflict, disease and poverty demands coherent information processing systems anchored on manipulative skills which help to coordinate and transform conceptual ideas, emotions and feelings into life supporting operations beyond the school setting. Herein, a sufficiently educated and enlightened population is a quality assurance for individual and social productivity, responsible leadership and prosperous future. A general desire to be educated in spite of the stagnation of opportunities and incentives as well as disenchantment among the teachers at all levels requires a well conceptualized humanistic approach to teacher education programme.

A coherent teacher education programme should 
systematically embrace integrated curriculum innovations which reflect the social, economic and political environment of a modern society to solve societal problems. (Oyekan, 2006), the purpose of teacher education is to produce wellqualified professional teachers that can adjust to the changing needs of the students and developmental prospects of the modern society.

\subsection{A history of Teacher Education in Pre-Colonial Nigeria: An Overview}

The origin and development of formal teacher education in the area that became Nigeria can be traced to the beginning of Western education in the pre-colonial Nigeria. The various church missions such as the Wesleyan Methodist, the Church Missionary Society, the Baptist, the Church of Scotland (Presbyterian) and the Roman Catholic were not only the pioneers, but very active in the area between 1842 and 1860 . Certainly, they contributed in no small measure to the development of teacher education in pre-colonial Nigeria. According to (Ajayi, 1965), the missionaries devoted their attention initially to the development of elementary (primary) education in the country, perhaps due to the little stipend the missions relied upon from their overseas headquarters, or as some Africanist scholars have argued, to further the imperialist design to limit colonial education to the basics, with the intention to produce educated Africans who (inadvertently) would participate in furthering imperial exploitation only. Discussing the system of education, (Adeyinka, 1971) opines that the missionaries trained their teachers through the apprenticeship pupil-teacher system. In such a system, the missionary teacher organized the school in his residence premises and some of his pupils lived with him as part of his family. (Fajana, 1970) added that at about 14 years, pupils ought to have written and passed the standard $\mathrm{V}$ examination. They were then recruited as teachers, but further received one hour instruction daily from the head teacher on teaching methodology. The duration of the course was two years, after which they would sit for the pupilteacher examination. Besides being the foundation of teacher education, the significance of this system was that it enabled the student-teachers to receive further training and education while contributing their quota in the formal educational needs of the society through teaching other pupils. From this very humble beginning, the system has developed into a more complex one involving college institutions and universities.

The first teacher training college, known as the Training Institution was established in Abeokuta in 1859 by the Church Missionary Society (CMS). The school was later moved to Lagos in 1896 after the missionaries were expelled from Abeokuta due to some disagreements between the missionaries and the local population/authorities most of whom were not very receptive to the new religion and the form of education being introduced by the missionaries. Perhaps, the preponderance of British presence and security assurances in Lagos influenced the decision to relocate to Lagos. Subsequently, it was again relocated to Oyo where it became known as the St. Andrews College, Oyo. Later, in
1896, it was established as a Grade II Teacher's College (now Emmanuel Alayande College of Education, Oyo) and it ranks the oldest Teacher's Training College in Nigeria. In 1897, the Baptist Mission established the Baptist Training College at Ogbomoso, and in 1905 the Wesleyan Methodist Missionary Society founded an institution for the training of catechists and teachers in Ibadan. The latter opened with only four pupils, but the number of pupils increased to twenty by 1918 when the institution became known as the Wesleyan College, Ibadan.

As the missionaries made frantic efforts to provide teacher training institutions in the Western part of the area that later became Nigeria, so were they trying to provide formal education and training for the early crop of teachers in the eastern part of pre-colonial Nigeria. According to (Fafunwa, 1974), under the apprenticeship system, homeless boys and children of converted village heads lived with the missionaries and were taught to become pupil teachers and catechists. This practice of using apprenticeship system to train teachers was very common in the Western part of precolonial Nigeria before and after the establishment of teacher training institutions. The training of teachers in the Northern part of what became Nigeria started with the opening of the schools in Nassarawa by the British government in 1909. Generally, the pre-requisite qualification for admission into a teacher training institution was standard IV. In addition, the candidate must have served as a pupil-teacher for two years, passed the pupil-teacher's certificate examination and would then qualify to act as an assistant teacher before starting another two-year training course in a teacher training institution (Fafunwa, 1974). At the end of the two years, the candidate would sit for and pass a prescribed teachers' certificate examination and would be certified. With the development of the system, the need to review the principles and practice of teacher education arose, leading to the inauguration of the Phelp-Stokes commission to undertake the task.

\subsection{Teacher Education Reforms in Colonial Nigeria: A Review of the Phelp-Stokes Commission's Report of 1925}

After the investigations and reviews done by the commission, the report severely criticized the teacher training system of the Christian Missions. According to the report, the teacher training system was unsatisfactory, the pupil-teachers were over-worked and under-paid, and the curriculum was poorly conceived. According to (Fafunwa, 1974), the supervisory system was inadequate and it seemed that the Missions were not adequately prepared for the task of training African teachers. In order to re-orientate and reorganize the teacher education system along the lines suggested by the report, and redress the problems of teacher education in the colony, two types of teacher-training institutions were recommended, namely,

(a) The Elementary Training College (ETC), for lower primary school teachers, and

(b) The Higher Elementary Training College (HETC), for 
higher primary school teachers.

Both the ETC and the HETC programs lasted for two years each and culminated in the award of Grades III and II Teacher's Certificates respectively. Any candidate willing to go for the ETC course would have served as a pupil-teacher for two years and on the successful completion of courses leading to the Grade III certificate had to teach again for at least two years before proceeding to the HETC for the twoyear Grade II program. This signifies a radical departure from the system adopted by the Christian Missions as it represents a more standard approach towards teacher education, training and development. However, the need for further reforms gave rise to the Ashby's commission.

\subsection{The Ashby Commission and Development of Teacher Education in Nigeria}

In 1959, Nigeria's federal government set up the Sir Eric Ashby Commission to investigate and determine the extent of manpower needs of the country especially within the education sector, with an eye on the future. After its works, the Ashby report prescribed that education was indeed the tool for achieving national economic expansion and the social emancipation of the individual (Urwick \& Aliyu, 2003). It recommended the establishment of four Federal Universities in the country, and also the introduction of some education-vital courses in them. Subsequently, five universities (instead of the recommended four) were established, viz: University of Nigeria, Nsukka (1960), Ahmadu Bello University, Zaria (1962), University of Ife, now Obafemi Awolowo University, Ile-Ife, (1962), University of Lagos, Lagos (1962) and University of Ibadan, first established as University College, Ibadan in 1948. A decade later, further demand for manpower compelled the country to establish the University of Benin (1972).

The implementation of the Ashby commission's report not only led to the establishment of university and introduction of courses, but also birthed new degrees. In other words, before the Commission's report, Bachelor of Arts in Education [B.A (Ed.)] or Bachelor of Sciences in Education [B.Sc. (Ed.)] or Bachelor of Education [B.Ed.], were not awarded by Nigerian universities. Graduates of degree awarding institutions earned Bachelor in Arts or Sciences (i.e., B.A., or B.Sc., etc. degrees). Also, some of the institutions ran programs leading to the award of PostGraduate Diploma in Education (PGDE), sometimes as affiliates of the University of London (Fafunwa, 1974). Reporting on the state of facilities for post-secondary education in Nigeria, the Ashby Commission observed that there was a gravely inadequate supply of trained and educated teachers in Nigerian secondary grammar schools, as opposed to the increase in demand for more of this category of education institutions. In view of the need to reconcile this contradiction particularly as regards teacher education, the Ashby Commission, among others, put forward these relevant recommendations;

(a) the establishment of more universities,

(b) the introduction of a bachelor's degree in education, i.e., B.A. (Ed.), B.Sc. (Ed.), or B.Ed.

(c) the training of more teachers for the nation's postsecondary schools.

The Commission further recommended teacher education program at the university level, observing that the new crop of Grade I teachers popularly referred to as well-qualified non-graduate teachers should be further trained at the university levels to man the secondary schools and teachertraining colleges. The commission therefore recommended the introduction of a Bachelor of Arts/Science degree in Education [B.A. (Ed.)/B.Sc., (Ed.)] in all Nigerian universities. The B. A. (Ed.) and B.Sc. (Ed.) according to (Fafunwa,1974) was launched at the University of Nigeria, Nsukka in September 1961 with 50 students. The University of Ibadan followed in 1963, Ahmadu Bello University in 1964, the University of Lagos in 1965 and the University of Ife (now Obafemi Awolowo University) Ile-Ife, in 1967. From the foregoing, it is evident that the Ashby's commission played a part in the development of teacher education in Nigeria. In fact, one major significant event in the development of teacher education in Nigeria was the transformation effect of the recommendations and subsequent implementation of the Ashby commission's report.

\subsection{Regionalization and Teacher Education in Colonial Nigeria}

The 1946 Richard's constitution divided the country into three regions - East, West and North and each had a regional assembly. Politically, the regions were dominated by three political parties; National Convention of Nigerian Citizens (NCNC) in the East, Action Group (AG) in the West and the Northern People's Congress (NPC) in the North respectively. Subsequently, the 1951 Macpherson constitution further strengthened the regional system and particularly empowered each region to pass laws on selected areas including education. Given this scenario, the regional system in colonial Nigeria set the stage for intensive political rivalry and also in the provision of social services particularly education in the regions. For the colonial Nigerian Western and Eastern regional governments, western education was a major priority, because while the Western regional government embarked on free Universal Primary Education (UPE) in 1955, the Eastern regional government and Lagos municipal government followed suit in 1957. On the other hand, the Northern regional government did not embark on the free UPE until the project was launched nationwide in September 1976. This delay in the implementation of UPE in the North proved deleterious on the long run. Meanwhile, the implementation of free UPE programs in the 1950s gave rise to crash programmes for massive production of trained teachers particularly in the Western region. New teacher training colleges were founded while some of the old ones were expanded to meet increasing demands for teachers. More so, in 1957, the University of Ibadan introduced a oneyear course for graduates leading to the award of diploma certificate in education, and in 1961, the University started a one-year associate-ship course for selected Grade II teachers 
who would take over the headship of primary schools after the successful completion of their studies (Fafunwa, 1974).

Furthermore, the Ashby commission's recommendation for Teacher's Grade I college was modified by the federal government to give rise to a new program, the successful completion of which earned a given candidate the Nigerian Certificate in Education (NCE). This program was meant for the training and preparation of teachers for the junior secondary schools and the teacher training colleges in the country. The schools where these new programs were run were popularly called the Advanced Teachers' Colleges (ATCs). The ATCs were established in parts of Nigeria in the 1960s, for example in Lagos and Zaria in 1962, Ibadan also in 1962 (but transferred to Ondo State where it became the Adeyemi College of Education). Others were established at Owerri in 1963, Kano in 1964 and Abraka in 1968 (Taiwo, 1986 in Jekayinfa, A.A. 2000). Admissions into these ATCs were open to candidates who held either the Teachers' Grade II Certificate and passed two subjects at the ordinary level of the General Certificate of Education (GCE) examination or West African School Certificate (WASC) examination with credit passes in at least two subjects, or those with GCE (O' level) with credit passes in five subjects including English language. Besides admission criteria, NCE graduation requirements was such that a candidate must pass a final examination in two science or two arts subjects, education and practical teaching, and must have passed ancillary subjects like general English, Library work, Health and Physical Education, offered during the program (Taiwo, 1986 in Jekayinfa, A.A. 2000).

\subsection{Teacher Education in Post Independent Nigeria}

Nigeria got her independence from the British imperialists in October 1960. The young nation experienced an unfortunate civil war between 1967 and 1970 which had adverse effects on her socio-economic development and consequently her educational system. The experiences of the civil war and the aftermath however rekindled the Nigerian faith in education as a major vehicle for national rehabilitation, reconstruction and reconciliation.

The National Curriculum Conference (NCC) document of 1969 spelt out the objectives and contents of all levels of education, including teacher education in Nigeria. The NCC provided the basis for the National Policy on Education (NPE) of the (Federal Republic of Nigeria,1977) which was later revised in 1981, opening a new chapter in the development of teacher training programs in Nigeria, because it signified a period when a Nigerian indigenous administration undertook educational reforms without any form of missionary or colonial inputs. It introduced the 6-3-3-4 system in which a six-year primary education was followed by a three-year junior secondary education and a three-year senior secondary education, before successful candidates would advance to (mostly) a four-year tertiary education in prescribed higher institution of learning. (Adeyinka, 1993) observed that with the introduction of the 6-3-3-4 education system, the need for a new orientation for secondary teachers and students arose.
This is particularly as it concerned the challenge of new curriculums, and acquisition of the basic knowledge. For the teachers, the skill to teach the new curriculum was also deficient requiring some training. To confront these challenges, NPE also provided that all teachers in the nation's educational institutions, from pre-primary to university, would be professionally trained. The implication of this is that more Grade II Teachers' colleges and more tertiary institutions of educational training would be established for the training of these teachers. In effect, after 1977, the Nigerian government embarked on the expansion of education facilities and institution with considerable emphasis on tertiary institutions for the training of secondary school teachers in order to ensure that teacher education objectives are realized. According to (Adeyinka, 1988), certain categories of educational institutions that came on board were charged with the responsibility of giving the required professional training for teachers. These are Grade II Teacher's Colleges, Advanced Teacher's Colleges, Colleges of Education, Institutes of Education, and National Teachers' Institute. The rise of these institutions certainly contributed in confronting the challenges to an appreciable extent. In addition, prior to the emergence of these institutions, the Nigerian federal government had, in preparation for the Universal Primary Education (UPE), approved emergency teacher training programmes which began in September, 1974. This was meant to produce estimated 163,000 additional teachers that will feed the rising demand in the education sector within the framework of the UPE scheme (Adeyinka, 1988). To obtain this large number of teacher trainees, the government mounted four different teacher education programmes for four different categories of school leavers, viz;

(a) One-year course for holders of the West African School Certificate (WASC).

(b) Two-year course for those who attempted WASC and failed or those with Grade III Teacher's Certificate.

(c) Three-year course for holders of Modern III Certificate or S-75 Certificate (i.e. recognized Secondary Class IV Certificate).

(d) Five-year course of holders of Primary School Certificate.

Unlike the civilian administration in the pre-civil war era which adopted some form of decentralization, Nigeria's military administration in the immediate post-civil war period were favorably disposed to centralized administration. In effect it launched the UPE nationwide in 1976, giving rise to unprecedented growth in school enrollment not only in the primary schools but also at the secondary and tertiary levels. This development, coupled with Nigeria's increasing population, brought more pressure on the demand for more teachers and, correspondingly, the demand for teacher education became even more enormous. The federal military government took over the financial responsibility for all Grade II teachers' colleges in the federation as part of the efforts to reposition the UPE program for efficiency. In addition, the government awarded bursaries to all pre-service 
teachers in the colleges of education and universities in other to support their studies, research and educational development generally. More so, it founded more teacher training institutions with diversified programs and encouraged universities to expand their teacher education programs, in a bid to provide a holistic approach to the challenge posed by deficits in qualified teachers.

\subsection{Teacher Education and National Development}

According to (Ukeje, 1988 in Wanekezi, Okoli and Mezieobi, 2011), pointed out that education unlocks the door to modernization and sustainable development but that, it is the teacher that holds the key to the door. Thus, the teacher has the responsibility of translating educational policies into practice and programmes into action. It is clear from the foregoing that the role of the teacher in sustainable development cannot be quantified, especially in training personnel in various areas of the workforce. For national development and peaceful co-existence to be attained, there is need to give priority to investment in human capital through teacher education and training. The Nigerian educational system needs to be responsive to the technological social and economic needs of the society and provide the type of human resources needed in the industrial and economic sector. Herein comes the role of effective teacher education programme to translate the needed skills, knowledge and attitudes to meet their needs and the societal ones.

\subsection{Teacher Education in Contemporary Nigeria: Trends, Challenges and Prospects}

The issues of teacher preparation, supply, status enhancement, motivation and retention as well as continuous training and retraining are at the heart of education reform at all levels. The overarching goal of human capacity development for the efficient and effective delivery of the Universal Basic Education (UBE), Education for All (EFA), and related Millennium Development Goals (MDGs) is that by 2015 Nigeria will have human resources base to manage and implement the UBE scheme (National Action Plan [NAP] 2006: 53). Thus, through strategic actions that include the following, the objectives seemed realizable:

- continued expansion of teacher training opportunities;

- continuous programme of enhanced status and professionalism for teachers through training and retraining, reviews of current remuneration packages, and enhanced career opportunities;

- programs designed to address the capacity needs of schools and educational management;

- building the capacity of the inspectorate services to improve quality;

- engaging civil society partners in the roles of quality assurance, monitoring, evaluation and impact assessment work at all levels.

The need and critical role of professionalizing the teaching profession, vested in the Teachers Registration
Council of Nigeria (TRCN), by virtue of the Teachers Registration Council Act, began in 2007 with the mandatory registration of all professionally qualified teachers. This action is equally matched with comprehensive training and in-service training seminars and workshops in the six geopolitical zones of Nigeria. More importantly, the TRCN has begun implementation of the NPE provision that all teachers in education institutions including universities shall be professionally trained [NPE Section 8(b) paragraph $72,2004]$. This was in a bid to ensure adequate supply of manpower in Nigerian schools in conformity with the goals of teacher education as specified in Section 8(b) of the (NPE, 2004), paragraph 70-79, the (NAP,2006) and the 10 Year Strategic Plan, among others. While the goal of the Strategic Plan is to design a teacher education framework, based on what teachers should know and do relative to Nigeria's new vision and mission, the (National Policy on Education, 2004 in Makoju, G.A.E. et al 2005p. 166 ); highlights the thrust of the ongoing reform noting that it aims to:

1. produce highly motivated, conscientious and efficient classroom teachers for all levels of our educational system;

2. encourage further the spirit of enquiry and creativity in teachers;

3. help teachers to fit into the social life of the community and the society at large and enhance their commitment to national goals;

4. enhance teachers' commitment to the teaching profession; and

5. Provide teachers with the intellectual and professional background adequate for their assignment and make them adaptable to changing situations.

It is significant and noteworthy that these approaches contributed immensely towards addressing teacher education challenges through training and retraining, instructional material development and availability, periodic renewal of teacher licenses, capacity building for reformed inspectorate service, support to the TRCN's mandate and enhancement of teachers' status and incentives. Today, teacher education is much improved than it was before and a few decades after independence. The NPE, released in 1977 and revised in 1981, 1998 and 2004 clearly articulates the importance attached to teacher education and affirms that no education system can rise above the quality of its teachers. The policy makes it mandatory for all teachers in Nigeria to be trained and stipulates $\mathrm{NCE}$ as the minimum qualification for the profession. It also provides that teacher education shall continue to take cognizance of changes in methodology and in the curriculum, even as it underscores the need for teachers to be regularly exposed to innovations in their profession. It further recognizes the need for in-service training as an integral part of continuing teacher education. Today, the statutory responsibility for teacher education in Nigeria is vested in Colleges of Education, Institutes of Education, Polytechnics, National Teachers Institute (NTI) and Nigerian Universities' Faculties of Education. Nigerian Polytechnics and Colleges of Education award the NCE 
which is a sub-degree but professional teachers are expected to at least, have diplomas obtainable after three years of fulltime study. The admission requirement for the NCE programme is Senior Secondary School Certificate (SSSC) or its equivalent with passes in five subjects including English language, and the curriculum for NCE teachers is designed to produce teachers exposed to a range of courses covering all that is required to make them competent professionals. New courses such as Computer Education, Mathematics and general English have been made compulsory for all $\mathrm{NCE}$ students. Also, relevant themes such as Nigerian constitution, environment/conservation education, population and family life education, HIV/AIDS education, drug abuse and women's education have recently been integrated into the curriculum. On its part, the NTI was established in 1976 by decree No. 7 of 1976 to offer upgrading programmes for teachers through distance learning. Over the years NTI has been providing in-service training for teachers during school holidays and weekends leading to the award of NCE, B.Ed. and Post Graduate Diploma in Education (PGDE) certificates. Similarly, Institutes of Education in the various universities have also been involved through distance learning and offer of part-time courses for the training of teachers who earn NCE, B.Ed., and PGDE certificates on successful completion of studies. On the other hand, faculties of education prepare pre-service teachers for B.Ed., B.A. (Ed.), M.Ed., and PhD degrees. There are four major components of the degree program in the Nigerian universities, namely, General Studies, Educational studies, Studies related to the students' intended field of teaching and teaching practice.

\subsection{Challenges Facing Teacher Education in Nigeria}

In spite of the various recommendations and reforms that targeted repositioning teacher education in the country for optimal performance, the challenges facing teacher education in Nigeria are still numerous. While some of these emerged with the changing socio-economic and political condition of the time, others evolved as a result of government neglect of the education sector especially as it concerns keeping pace with emerging realities, such as, servicing Nigeria's growing population, education demand and needs with matching supply of education services and facilities. Some of these challenges are specifically examined as follows;

\subsubsection{Poor Policy Implementation}

Poor policy implementation is a challenge to quality delivery of teachers' education. The poor quality delivery is responsible for the abysmal low performance of teachers' graduates from the institutions of higher learning in Nigeria. (Anyakoha, 1994) argued that our policies are written by knowledgeable writers who have foresight and believe strongly in what they write for the future but the problem comes when it comes to translating theory into practice by implementers. However, several factors could be adduced as inhibitors to smooth implementation of educational policies and thereby resulting to poor quality delivery. Such as government underfunding of education and injudicious utilization of available funds by implementation agencies: vice chancellors, rectors, provosts, deans of faculties, heads of department etc. when funds meant to deliver quality education is misappropriated or embezzled, the education which learners receive becomes worthless.

\subsubsection{Poor Conditions of Service and Brain Drain Syndrome}

In Nigeria, teachers' conditions of service do not hold enough incentives to attract and retain the best brains in Nigerian schools (Osokoya, 2012). As a result of the weakening attraction to the teaching profession, and by extension the resultant dwindling enrolment in the teacher education programs, those who remain in the profession maintain relatively low social status with accompanying psychological problems. Consequently, within the remaining pool, some teachers either seek opportunities in other sectors (within the economy) with better service incentives or even migrate to other countries where teachers' conditions of service are much better, in search of greener pastures.

The quality or standard of education in Nigeria has reduced in recent years because of, among other factors, the brain drain phenomenon, (i.e., the drift of many brilliant, intelligent and more experienced teachers and university lecturers to countries where they were offered better remunerations and conditions of service). This syndrome is, to a large extent, attributable to inadequate incentives, poorly equipped education system in an increasingly hostile working environments, inadequate social recognition, delay in payment (and sometimes denial) of teachers' salaries, among others. The reliance on inexperienced, and in some cases unqualified teachers and lecturers in the various educational fields and institutions in the country definitely affects the quality of students' work, and of graduates who are eventually employed to service the educational manpower needs, as well as the economy. This vicious circle contributes to the lowering status of education in the universities, colleges of education as well as secondary and primary schools (Osokoya, 2012), even as the trend impacts on the economy negatively.

\subsubsection{Quality Assurance and Internal Efficiency Issues}

The academic and emotional qualities of intending candidates for teacher education are critical for quality assurance and internal efficiency in teaching professions. In Nigerian tertiary schools, a trend has been evolving to the effect that candidates who apply to higher institutions for teacher education are those who have either been denied admission in their choice areas of study, or are basically unqualified for admission into such popular professional courses as medicine, law, engineering, architecture etc. The usual shortage of applicants seeking admission into programs that would prepare them as teachers in universities and colleges is a pointer to why admission and placement in education programs is not as rigorous as it is in other programs earlier named. This is mostly opposed to the international standards for teacher selection. For example, the International Labor Organization (ILO) recommends that 
teachers should be selected on the basis of moral, intellectual and physical qualities. Also, in more developed climes like the United Kingdom, applicants are compulsorily expected to possess certain intellectual qualities and personal characteristics before they are admitted for training (Lassa, 1998). In contrast, the Nigerian Universities, College of Education and Polytechnics conduct students' admissions based primarily on obtaining the minimum academic requirements while other internationally recognized prerequisites such as emotional stability, physical fitness or qualities, moral uprightness and communication proficiencies are hardly given considerations.

In addition to the above, the low quality of teachers produced through in-service training by NTI is a serious challenge to teacher education in the country. Some Nigerian scholars have noted that most of the teachers upgraded to Teachers Grade II by NTI were very deficient not only in the academic subjects they teach, but also in techniques of teaching (Obanya, 2008), (Enukora et al, 2003). Perhaps, the most unpleasant challenge is one posed by the ongoing Pivotal Teacher Training Program (PTTP) which is currently being executed by the NTI. The PTTP is an intensive program of the federal government designed to raise teachers to implement the UBE program. Introduced to address the gross shortage of qualified teachers at the inception of UBE in 1999, it was apparently in search of cost effective alternatives towards bridging the shortage gaps in the system (FGN, 2003). Structured as a 15 month course including 12 weeks school experience and three-month internship in a primary school, the PTTP's mode of teaching combines faceto-face contact at weekends/holidays with self-instruction course materials and school teaching experience, after which the candidates are certified and deemed qualified to teach. Critics of the program have, however, condemned the program's low academic quality, its products and more fundamentally the poor standards of admission requirements into it (Enukora et al, 2003), (Osokoya, 2012). The weight of these quality assurance issues is concomitantly brought to bear on the internal efficiency of Nigeria's education system, hence deepening the crisis in the sector.

\subsubsection{Insufficient Knowledge and Use of Information Communication Technology (ICT)}

Another major challenge to teacher education in Nigeria is that of insufficient knowledge and use of ICT in a globalizing world. The knowledge, and use, of computer technology as well as the internet is a necessity for all teachers to guarantee the relevance of the system and its products in the $21^{\text {st }}$ century. Many schools in Nigeria still operate the traditional education system with little or no adaptation to ICT. To benefit from the ubiquity of information and to facilitate communication among professional networks, school teachers need, not only be trained and re-trained in ICTs, but facilities must be provided by government to enable teacher and their students access to these remain uninterrupted, more so that the world is gradually becoming a global village. For our future teachers to be able to operate effectively and efficiently, they must imbibe the new technologies and methodologies of the modern times (Osokoya, 2012).

\subsubsection{Non-Professionalization of Teaching}

Many teachers in Nigeria have not measured up to the minimum international standard. This is because a large number of untrained and half-baked personnel are still retained in the system, leading to a scenario in which career in teaching is not yet professionalized. Many unqualified teachers are still in the employment of some States Teaching Service Boards, while most higher education lecturers are yet to undergo training in education. Until government makes this training mandatory and pursues the policy vigorously, teaching will continue to be open to anyone and this situation holds the potentials of further eroding professionalism in teaching profession (Osokoya, 2012). Certainly, this has other wider socio-political and economic implications given the fact that education remains a very essential component that produces a healthy and prosperous nation.

\section{Conclusion and Recommendations}

In Nigeria, like many other developing countries in the world, teaching is the most vital and strategic profession for national development. This is so because teaching is that important activity which makes possible the acquisition of knowledge and skills that brings about the mark of an educated and useful person in the society. Education remains a single major factor for national development. The teacher is central in this enterprise, and no tool has been able to replace the teacher yet; this is because no educational system can rise above its teachers. The teacher holds the remedy to the many problems ravaging Nigeria. The teacher's efficiency matters in these regards. The central purpose of teacher education according to the NPE is to provide teachers with the intellectual and professional background for their assignment. Notwithstanding the laudable objectives and efforts made by various administration of Nigerian government, this paper concludes that although various Nigerian governments did a lot to improve the system, teacher education programs in Nigerian higher institutions are largely lacking in quality neither do they conform to international standards. This situation is mainly because of the governments' inability to keep up their commitments in the education sector in a way that answers to the needs and the changing (socio-economic) dynamics of the country, in spite of the long years of the oil booms and the vast amount of foreign exchange earned.

\subsection{Teachers' Professional Competences}

Teacher's professional and academic competencies are seen in their ability to make use of the learning opportunities available in the environment. This means their willingness to take active part to analyze changes in the environment with other members of the work community to see these changes in relation to teachers and the school possibilities to determine which changes and outcomes that are of the greatest relevant to the socio-economic and political 
development of the community's need.

Teachers competence will be enhance as they have close contact and diverse interaction with its environment as well as being able to anticipate and influence factors which will bear upon teaching in the future. So this calls for teachers having mastered their various subjects to also have command over a wide repertoire of different teaching methods and strategies (pedagogy) as well as understanding of the learning process of students. (Shulman,1987) in introduction of pedagogical content knowledge stressed the combination of content knowledge and pedagogic skills that are necessary for the organization of classroom situations and activities of learners. He defined pedagogical content knowledge as "the particular form of content knowledge that embodies the aspects of content most germane to its teach-ability" it means that both teacher expertise and teacher knowledge of the subject matter differ from ordinary scholarly knowledge and pedagogy. In other words, teachers should be able to fuse the knowledge of the subject matter and pedagogical knowledge into pedagogical content knowledge in their classroom activities.

This will also include an understanding of what make the learning of a specific concept difficult and the instructional strategies that could help in presenting different aspects of the instructional process. Knowledge of what motivate students' attitude toward different subjects is also embedded in the pedagogical content knowledge. The fact remains that teacher who knows their work and its meaning are the foremost goal of teacher education. Being a teacher means one's ability to encounter change and influence change. Therefore changes in pupils, their living environment and society as a whole require sensitivity and willingness to anticipate future development. One of the challenges of teachers is still the ability to analyze change in the environment with other members of the work community to see these changes in relation to the teachers and the school possibilities to determine which changes and outcomes are of the greatest relevance to the development of teaching.

Teacher education needs close contact and diverse interaction with its environment in order to be able to anticipate and influence factors which will bear upon teaching in the future. This is so because being a teacher in future will mean ones willingness to take active part in influencing social development.

\subsection{Redefine Teaching as a High Level Profession}

2.2.1. Rethink the content of teacher education to attain teacher quality: The way in which practicing teachers learn depends on many factors - culture and tradition, existing institutions, systemic characteristics, etc. Specific designs of teacher education must be context specific, and modelled in function of specific needs (education aims, processes that are already in-place, developing these skills and to understand the in depth context of the schools in which they teach. Teacher education programmes should be designed as an incentive to bring the right people into teaching and to make it adequate to the country's specific needs, depending on the quality and the quantity of future teachers that it is considered suitable.

2.2.2. Increase the coherence between the education received by teachers and what actually happens in the classrooms: The role of practical field-experience in teacher education has to be revaluated: to include practicum during initial teacher education allows to familiarize aspirant teachers to classrooms, to prevent "reality-shocks" at the beginning of their teaching career, to link pedagogical theory with practical problems and to construct a sound professional identity. The modalities (sole observation, tutoring and assistance, full responsibility of a class, small support tasks) can be adapted to the particular context of each country. Research shows that soon-to-be-teachers that have had an extensive training in schools perform better as teachers.

2.2.3. Systematically put into place teacher quality mechanism: Systematic certification for teachers and accreditation for teacher education providers have to be put into place. Educational authorities can establish professional standards, independently to what is taught in the teacher education programmes. This is also a way to influence on these programmes, and make their outcome closer to what the educational system needs, in terms of skills and competences. To raise the requirements to certify teachers allows improving teacher quality. The establishment of standards to certify teachers, and/or to accreditation teacher education providers can allow to "even out" teacher education, to bring clearness and predictability into the system.

\subsection{Design a More Coherent Educational System}

2.3.1. See teacher education as a continuum: The coherence of initial teacher education and professional development has to be improved. In order to be as effective as possible, teacher education has be to thought of, and teacher education policy structured as, a continuum of teacher learning (that includes formal and informal preparation activities). Teacher education is a life-long experience that goes from their initial education to their retirement. The several stages that compose teacher education have to be intrinsically connected. The initial education that teachers receive constitutes a solid base of the knowledge and the skills that they will need for their task, and continuing training allows them to update this "patrimony" and to adapt it to the changes of the teaching environment. The articulation of these different elements is fundamental, since undoubtedly there are synergies between them, that influence what and how to teach.

2.3.2. Acknowledge the importance of continuing education: Continuing training has to be perceived as an integral element of teachers' professional responsibilities. This is not generally the case, since traditionally; teacher education has focused mostly on initial teacher education. Continuing training should be closely articulated with initial teacher education: many times, continuing training programmes are carried off with little coherence with the initial education received by teachers. These continuing 
training programmes are effective when they have a certain length, that are based on school's needs and allow interaction among teachers (peer-to-peer, mentoring). Since continuing training should form a part of teacher responsibilities, incentives mechanisms have to be put into place, and it has to be taken into account in teachers' work load, continuing training etc.). A complete teacher education combines strong subject-matter and pedagogical knowledge, the ability to collaborate with diverse actors (students/ colleagues/ administrators), and the capacity to continue represents a tool that is fundamental in the case of low quality initial teacher education.

2.3.3. Weave closer cooperation bonds between the different providers of education: There is the need to weave closer cooperation bonds between the different providers of teacher education, in order to articulate teacher education as a continuum. Initial and continuing training for example should be provided by the same institutions in order to assure a better coordination and to allow contacts between teachers already in service, and soon-to-be teachers. The first group could offer their practical experience, and teachers that are still in education could share the latest novelty in research and theory.

\subsection{Explore Alternatives for Teacher Education Provision}

2.4.1. Support new school-based effective teacher education programmes: Emphasis should not be put on the teachers' specific needs, but on the creation of a suitable learning environment for students. Schools have to be at the centre of teacher education programmes, and it is their needs that have to be taken into account for the design of these programmes. Research indicates that programmes that are linked to specific school needs are more effective, especially activities based on demonstration and peer-review. They allow synergies among the teachers and the staff of the school. There should be tight linkages between teachers' own professional development, the responsibilities that they are given to them and the school's goals. This is also a way to assure that motivation for continuing training will not be led by only individual teacher advancement, but towards more collective goals, oriented toward the implementation of innovation.

2.4.2. Making teacher education more flexible: Alternative teacher education programmes should be created. Their main purpose is to increase the supply of teachers in areas of need, geographical, or relative to a particular subject (IT, languages, mathematics, etc.). Nigeria can "customize" these programmes according to their specific needs and the type of "profile" they want to attract into the teaching profession, modifying the requirements to enter, the modalities to certify teachers, the way they are financed. A comprehensive design allows articulating these routes to the existing ones: traditional and alternative teacher education programmes should not be seen as competing, but as complementary. Sponsored generally at the local scale, alternative certification programmes are oriented toward helping new teachers to learn their jobs in particular contexts; this is why they are general school-based and school-oriented.

\subsection{Innovate in the Designs of Teacher Education}

It is important to identify the main possible design of teacher education, and the trade-offs in terms of costefficiency that exists between their different phases.

2.5.1. Alternative pathways vs. traditional pathways: Complementary teacher certification and accreditation mechanisms can be designed to manage the risk of seeing the quality of teachers lower as a consequence of this new development. For a country, an option could be the development of alternative pathways, as long as it is carefully assessed and designed comprehensively and coherently.

2.5.2. Initial teacher education vs. continuing training: there is a certain complementary between both phases of the education continuum. Initial teacher education could be shortened, and the resources economized could be used to strengthen continuing training, based in schools. For Nigeria, this change is worth consideration, but would need careful assessment. Even if continuing training should not have to compensate for a bad quality initial teacher education, in the case teachers do not have a sufficient level to teach, such measures could "correct", and compensate this "deficit" in teaching skills and knowledge.

\subsection{Provision of Clinical Experience is also Critical}

Clinical experience should be provided to teacher candidates early and throughout their education program, so that they would, early in their training, develop an image of what teaching involves and requires. The significance of this is that it would expose them to the intricacies and thinking involved so that they can better make sense of how the ideas and theories they encounter in their coursework fit in the process of clinical practice. Students' teaching experiences should be longer than the currently prescribed three months. It should be extended to, at least, one academic year in Primary and secondary schools. Moreover, teachers' education program should be re-structured to five-year program involving four-year theoretical coursework, and one year clinical experiences.

\subsection{Strong Linkage Between Teacher Learning and Professional Development}

(i) Having a clear vision of what pedagogical content and skills teachers must have,

(ii) Assessing teachers for their current capacity in those years,

(iii) Developing professional evolution to fill gaps,

(iv) Evaluating the effectiveness of those programs for improving the targeted content and instructional skills, in conjunction with the short or long term improvement in students' achievement or other academic outcomes,

(v) Teachers co-planning, co-teaching, co-debriefing and co-reflecting will give evidence of understanding through professional discourse and then proof is in the application of discussion commitment,

(vi) The need for formal and validated protocols for 
observations and for deeper gauges of teachers' performance,

(vii) The need for transparency regarding the rating criteria to be used and reveal their scientific and pedagogic evidence base.

\section{References}

[1] Abdukareem, A. Y. (2001). Nigeria University and the Development of Human Resources. In N. Nwagwu, E. T. Ehiametalor, M. A. Ogunu \& M. Nwadiani (Eds). Current Issues in Education Management in Nigeria. Benin City: Amik Press.12(1), 127-129.

[2] Adewuyi J.O. (2012). Functional Teacher Education in Addressing Contemporary Challenges in Nigeria. Being a Lead Paper Presented at the 4th National Conference of South-West Zonal Conference at Federal College of Education (Special) Oyo, held between 17th -20th July, 2012.

[3] Adewuyi J.O. and Ogunwuyi, A.O. (2002). Basic Text on Teacher Education. Oyo. Odumatt Press and Publishers.

[4] Adeyinka, A.A. (1971). The development of secondary grammar school education in the western state of Nigeria, 1908-1968. M.Ed. Dissertation, University of Ibadan.

[5] Adeyinka, A.A. (1993). The development of secondary education in Oyo, Ogun and Ondo States of Nigeria, 19081980. Occasional publication 1, Faculty of Education, University of Ilorin, Nigeria.

[6] Adeyinka, A.A. (1998). History of Education in Nigeria. Mimeograph.

[7] Afe, J.O. (1992). Trends in Teacher Education: The case of colleges of Education in Nigeria. In Eimuhi J.O. and Otomewho, G.A. Access, Equity and Quality in Higher Education. NAEP Publication.

[8] Afe J.O. (1995). Strategies for educating migrant fishermen and their Family the Nigeria Teacher. Today. A journal of teachers education. 4th October. Pp. 66-72.

[9] Ajayi, J.F.A (1965). Christian missions in Nigeria 1845-1881: The making of new elite. Ibadan History series 1. London: Longman.

[10] Anyakaoha E.U. (1994) Strategies for enhancing the teaching of home economics in junior secondary school level. Nigerian Vocational Journal Vii: 61-70.

[11] Bofarin. T.A. (1986). In Attitudes to training. Unpublished seminar paper: Lagos state University.

[12] Darling-Hammond, L. and Bransford, J. (2005). Preparing teachers for a changing World (what teachers should learn and be able to do) - Published by Jossey-Bass. pp 118 - 441.

[13] Enukora, et al. (2003). Education Sector Status Report. Federal Ministry of Education.

[14] Fafunwa, A. B. (1974). History of Education in Nigeria. Great Britain, Clarke, Doble \& Brendon Ltd Plymouth. 196-204.

[15] Fajana, A. (1970). 'Missionary Educational Policy in Nigeria, 1842-1882'. West African Journal of Education. 14 (2).
[16] Jekayinfa, A.A. (2000). Development of Teacher Education in Nigeria. West African Journal of Education Research, 3(1), 129-133.

[17] Lassa, P. (1998). 'Teacher production: Focus on Nigeria'. In R. Akpofure (ed.), the state of education in Nigeria, UNESCO. Abuja. pp. 70-83.

[18] Makoju, G.A.E. et al (2005). Nigeria Education Sector Diagnosis, a framework for re- engineering the Education Sector. Education Sector Analysis Unit, Federal Ministry of Education, Abuja, Nigeria P. 165-186.

[19] Musset, P. (2010), "Initial Teacher Education and Continuing Training Policies in a Comparative Perspective: Current Practices in OECD Countries and a Literature Review on Potential Effects", OECD Education Working Papers, No. 48, OECD Publishing. http://dx.doi.org/10.1787/5kmbphh7s47h-en

[20] National Action Plan document (NAP) 2006

[21] National Policy on Education. (1977). Federal Ministry of Information, Lagos. Federal Republic of Nigeria.

[22] National Policy on Education $4^{\text {th }}$ Edition. (2004). National Education Resource and Development Council Press, Lagos. Federal Republic of Nigeria.

[23] Obanya, I.O. (2008). Teaching and Cheating. Ibadan: University of Ibadan Inaugural lectures series.

[24] Obebe B.J, (1993). In making our education culture based. Daily Times October 10th

[25] Olaniyan, D.A. and Okemakinde, T. 2008. Human Capital Theory: Implications for Educational Development. Pakistan Journal of Social Sciences, 5: 479-483.

[26] Ogunwuyi, A.O. (2010) Concept, Goals, Aims and Objectives of Education. In G.O.

[27] Okemakinde, T., Adewuyi, J. O., and Alabi, C. O. (2013). The Place of Teacher in National Development in Nigeria. European Journal of Humanities and Social Sciences Vol. 19, No.1, 2013.

[28] Oyekan, S.O. (2006): Foundations of Teacher Education. Ibadan. Ben Quality Prints.

[29] Osokoya, I. (2012). Teacher Education in Nigeria: Past, Present and Future Challenges. The Online Journal of Academic Leadership (Vol. 10, Issue 1).

[30] Philip, A. et al (2007). The professional Development of Teachers: Practice and Theory. By Kluver Academic Publishers, New York, Boston, Dordrecht, London, Moscow.

[31] Report of the National Curriculum Conference (NCC), 8-12 September, 1969

[32] Shulman's (1987) in Nwachukwu prince Olulube . Teacher Education School Effectiveness and Improvement.

[33] Talabi, J.K. (1985) Teacher education and socio-cultural changes. Perservice teacher. Nigeria Journal for curriculum studies. 3.(1).

[34] Tony Townsend and Richard Bates (2007). Handbook of Teachers Education: Globaslization, standard and professionalism in times of change. Published by Springer, Dordrecht, The Netherlands. 
[35] Urwick, J. and Aliyu, B. (2003). Towards the re-dynamisation of Nigeria's education system. A report of the Symposium on the future of Nigerian education, Teddington Lock, Council for Education in the Commonwealth. pp.7-8.

[36] Ukeje, I. (1988) Training teachers to recognize and identify gifted children-Inner City Gifted Project. Paper presented at the annual workshop for the Inner City Gifted Project, Newark, NJ.
[37] Ukeje B.O (1996). Teacher education for national Development in P.N. Maiyanga). Teachers Education: An imperative for National Development Kaduna. National Commission for colleges of Education.

[38] Wanekezi, A.U.,. Okoli, J. and Mezieobi, S. A. (2011) Attitude of Student-Teachers Towards Teaching Practice In the University of Port Harcourt, Rivers State, Nigeria. Journal of Emerging Trends in Educational Research and Policy Studies 2(1): pp 41-46. 